\title{
Evans syndrome
}

INSERM

\section{Source}

INSERM. (1999). Orphanet: an online rare disease and orphan drug data base. Evans syndrome. ORPHA:1959

Evans syndrome is a rare chronic hematologic disorder characterized by the simultaneous or sequential association of autoimmune hemolytic anemia (AIHA; a disorder in which auto-antibodies are directed against red blood cells causing anemia of varying degrees of severity) with immune thrombocytopenic purpura (ITP; a coagulation disorder in which auto-antibodies are directed against platelets causing hemorrhagic episodes) (see these terms) and occasionally autoimmune neutropenia, in the absence of a known underlying etiology. 